Рекомендована д. фрармац. наук, профр. В. В. Трохимчуком

УДК 615.1:338.24: 005

DOI 10.11603/2312-0967.2017.2.7909

\title{
ДОСЛІДЖЕННЯ РОЛІ ПСИХОЛОГІЧНОГО СТИМУЛЮВАННЯ ПЕРСОНАЛУ В СОЦІАЛЬНОМУ МЕНЕДЖМЕНТІ ФАРМАЦЕВТИЧНИХ ОРГАНІЗАЦІЙ
}

\author{
(c) А. А. Котвіцька, О. М. Вороніна, І. В. Кубарєва, Н. В. Чмихало \\ Національний фрармацевтичний університет, Харків \\ socpharm@ukr.net
}

\begin{abstract}
Мета роботи. Проведення дослідження ролі психологічного стимулювання персоналу в соціальному менеджменті фрармацевтичних організацій.

Матеріали і методи. Використано методи наукового аналізу, зокрема його прийоми узагальнення та групування, а також соціологічні методи дослідження.

Результати й обговорення. У ході проведення дослідження зазначено психологічні методи соціального менеджменту, фрактори психологічного стимулювання персоналу та визначено наступне: 68,9 \% опитаних працівників вказали, що в практичній діяльності фармацевтичних організацій не повною мірою використовуються психологічні прийоми стимулювання персоналу, недостаньо використовується метод щодо формування робочих груп за критерієм психологічної сумісності працівників (72,8 \%) та майже зовсім не використовується психологічноорганізаційний метод стимулювання персоналу (86,6 \%), тобто при організаційному нормуванні та регламентуванні праці майже не враховується індивідуальна психологія працівника.

Висновки. Результати дослідження свідчать про зростання ролі саме психологічного стимулювання персоналу в соціальному менеджменті фрармацевтичних організацій, що пояснюється змінами змісту сучасної суспільної праці, її інтелектуалізації та зростанням соціально-культурного й професійного рівня працівників. Визначено, що обов'язковою необхідністю $€$ цінування кожного працівника як окремої особистості, як важливого члена колективу фрармацевтичної організації, що має спільні цілі та йде до конкретної мети. Психологічне стимулювання персоналу обов'язково повинно бути застосоване в управлінні фрармацевтичною організацією з метою підвищення соціальної активності співробітників.
\end{abstract}

Ключові слова: психологічне стимулювання; персонал; соціальний менеджмент; фрармацевтичні організації.

Вступ. У сучасних ринкових умовах, не зважаючи на певні перетворення в економіці країни, більшість фрармацевтичних організацій широко не використовує в менеджменті соціально-психологічний підхід до управління персоналом. Водночас як в економічно розвинених країнах використовується та постійно удосконалюється антропо-соціальний підхід до управління персоналом організації, заснований на визнанні пріоритету людини як окремої особистості та основної продуктивної сили суспільства, що приводить до активного розвитку саме соціального менеджменту організації як основного джерела економічного розвитку країни та демократизації суспільних процесів.

У наукових працях П. Друкера, Л. В. Балабанової, О. В. Сардак, В. М. Толочка, В. Г. Щербак, О. О. Хандій $[1,2,4,5,6]$ та інших, які присвячені проблемам управління трудовими ресурсами підприємств різних галузей народного господарства, використовуються переважно традиційні методи стимулювання персоналом, які базуються на матеріальних та нематеріальних стимулах.

Для сучасних фрармацевтичних організацій актуальним $є$ використання в повному обсязі як традиційних методів стимулювання персоналу, так і методів, які враховують соціально-психологічні особливості персоналу та відповідні мотивуючі чинники, що сприятиме розвитку трудового потенціалу організації та підвищенню її ефрективності.

Мета роботи. 3 огляду на зазначене, метою роботи стало дослідження ролі психологічного стимулювання персоналу в соціальному менеджменті фрармацевтичних організацій.

Матеріали і методи. Використано методи наукового аналізу, зокрема його прийоми узагальнення та групування, а також соціологічні методи дослідження.

Результати й обговорення. На сьогодні з урахуванням нестабільної ситуації в економічному розвитку країни, в умовах підвищення напруги між різними соціальними прошарками населення, стрімкого розвитку комп'ютерних технологій та постійного підвищення інтелектуалізації всіх видів праці персоналу фармацевтичних організацій значною мірою зростає роль психологічних стимулів в соціальному управлінні. За таких умов раціональний розподіл праці в організації забезпечує високу продуктивність праці лише в тому випадку, якщо керівник враховує індивідуальні та психологічні особливості кожного працівника.

ISSN 2312-0967. Pharmaceutical review. 2017. № 2 
Фармацевтичний менеджмент, маркетинг та логістика Pharmaceutical management, marketing and logistics

Досліджуючи питання щодо психологічного стимулювання трудової діяльності персоналу у фрармацевтичній організації, слід зазначити, що традиційним є застосування методу «покарання та винагороди»персонал виконає роботу або під впливом загрози покарання, або за майбутню винагороду. У вигляді «покарання» до персоналу організації застосовують різні стягнення, позбавлення премій, погрози щодо позбавлення робочого місця. У вигляді «винагороди» - підвищення зарплатні, заохочення, премії, путівки і т. д. Для сучасних фрармацевтичних організацій ця система заохочень та покарань не $\epsilon$ ефрективною.

На наш погляд, актуальною на сьогодні є відома 3 теорії менеджменту концепція «людських відносин» Елтона Мейо, яка домінувала в теорії управління організацією до середини 1950-х років. За відповідною теорією в управлінні організації домінуючими $€$ психологічні мотиви, врахування людського фрактора, особлива увага приділяється соціальній взаємодії та груповій поведінці, що значно впливає на продуктивність індивідуальної праці. Саме під впливом соціально-психологічних фракторів в організації фрормується суспільна свідомість, психологічні зв'язки в колективі та ставлення до праці [2].

Спираючись на зазначену концепцію, слід зазначити, що психологічний стан працівника фрармацевтичної організації може як сприяти підвищенню продуктивності та ефективності праці, так i, навпаки, може знижувати трудову активність людини (втома, роздратування, апатія, постійний стрес від перенапруження або постійного психологічного тиску керівництва тощо).

На нашу думку, психологічне стимулювання персоналу обов'язково повинно бути застосовано в управлінні фрармацевтичною організацією 3 метою підвищення соціальної активності співробітників. Саме психологічні стимули впливають переважно на свідомість працівників, їх соціальні, моральні, естетичні інтереси та здійснюють соціальне стимулювання трудової діяльності. Психологічні методи стимулювання включають різноманітну низку прийомів, які розроблено соціологією, психологією, соціальним менеджментом та іншими науками, що вивчають людину і вплив на її поведінку за допомогою методів анкетування, тестування, опитування, інтерв'ю та ін.

За результатами опрацювання наукових джерел інфрормації $[1,5,6]$ до психологічних методів соціального менеджменту доцільно віднести наступні: 1) гуманізація праці (дотримання встановлених санітарно-гігієнічних норм, ліквідація монотонності, кольорове офрормлення приміщення, використання спеціальної музики тощо); 2) психологічні прийоми стимулювання або способи психологічного впливу на персонал (похвала, прохання, позитивне переконання, порада, наставництво тощо); 3) задоволення професійних інтересів (самовираження у професійній діяльності, розвиток особистості, отримання задоволення від праці); 4) професійний відбір та навчання персоналу (кар'єрне зростання); 5) фрормування робочих груп за критерієм психологічної сумісності працівників; 6) психологічно-організаційні методи (організаційне нормування з урахуваням індивідуальної психології працівника, регламентування праці, демократична трудова дисципліна); 7) встановлення гармонійних стосунків між керівниками та підлеглими; 8) залучення працівників до процесу управління.

У ході проведення дослідження щодо використання зазначених вище психологічних методів соціального менеджменту в практичній діяльності фрармацевтичних організацій було проведено анкетне опитування працівників аптек та фрармацевтичних фрірм Харкова та Харківської області.

В опитувані брали участь 84 людини, серед яких $62 \%$ жінок та 38 \% чоловіків. Серед жінок 43 \% працівники аптек, з яких $13 \%$ - це завідувачі аптек та $30 \%$ провізори. Серед чоловіків $10 \%$ - це провізори аптек та $28 \%$ персонал середнього рівня управління фрармацевтичних фрірм.

На підставі результатів дослідження слід зазначити, що з 84 опитаних 68,9 \% вказати, що в практичній діяльності фрармацевтичних організацій не повною мірою використовуються психологічні способи стимулювання персоналу, недостаньо використовується метод щодо фрормування робочих груп за критерієм психологічної сумісності працівників (72,8 \%) та майже зовсім не використовується на відповідних організаціях психологічно-організаційний метод стимулювання персоналу (86,6 \%), тобто при організаційному нормуванні та регламентуванні праці майже не враховується індивідуальна психологія працівника.

Відносно наявності психологічної служби в організаціях, слід зазначити, що 21 \% опитаних працівників аптек вказали на існування відповідної служби в аптечній мережі та 56 \% працівників фрармацевтичних фрірм, але тільки 38 \% усіх опитаних користуються послугами психологічної служби або відвідують психологічні тренінги.

У ході дослідження визначено, що психологічну службу фрармацевтичних організацій, як правило, представляє один штатний психолог-консультат, оскільки не кожна відповідна організація може дозволити собі мати повноцінну психологічну службу. Основною причиною низького рівня користування персоналом фрармацевтичних організацій послугами психологічної служби $є$ неефективність використання таких принципів, як прозорість, компетенція та конфріденційність.

Таким чином, психологічний вплив полягає в регулюванні взаємовідносин між членами колективу фрармацевтичної організації з метою створення в ньому сприятливого психологічного клімату. Психологічне стимулювання персоналу повинно базуватися на врахуванні різноманітних фракторів: своєчасному інфрормуванні персоналу про результати праці;

ISSN 2312-0967. Фармацевтичний часопис. 2017. № 2 
моральному спонуканні до якісної праці, активної творчості та прояву ініціативи; врахуванні психологічних особливостей працівників; стимулюванні до перспективного, соціального і професійного зростання; забезпеченні справедливості в отриманні матеріальної винагороди.

Поряд з об'єктивними фракторами на трудову активність персоналу фрармацевтичної організації у колективі значно впливають такі суб'єктивні фрактори, як вже сорормований психологічний клімат у колективі, розподіл ролей, соціальний статус робітника, характер неформальних зв'язків, індивідуальне ставлення до праці, настрій. Необхідність врахування в управлінні орармацевтичною організацією суб'єктивних фракторів зумовлена тим, що психологічно схожі люди об'єднуються в неформальні групи, а це вносить суттєві корективи в їх поведінку. Група може нав'язувати людині певні норми поведінки, корегувавти індивідуальну діяльність. Людина, в свою чергу, повинна зважати на існуючі в групі норми поведінки, правила, традиції, а також враховувати колективну думку.

Суттєвий вплив на ефективність соціального менеджменту фрармацевтичної організації має поведінка керівників. Оскільки їх завданням є не лише турбота про досягнення фрінансових результатів діяльності організації, але і забезпечення позитивного психологічного клімату в колективі та соціально-психологічна мотивація працівників. Чим більшою $є$ керована організація, тим вищими $є$ вимоги до продуктивності праці, і тим складнішою буде система мотивації та психологічного стимулювання. В трудовому колективі, основаному на засадах позитивного співробітництва, люди більш працелюбні, більш креативні та більш стійкі до робочого перевантаження.

Висновки. Результати дослідження свідчать про зростання ролі саме психологічного стимулювання персоналу в соціальному менеджменті фрармацевтичних організацій, що пояснюється змінами змісту сучасної суспільної праці, її інтелектуалізації та зростанням соціально-культурного й професійного рівня працівників. Визначено, що обов'язковою необхідністю $€$ цінування кожного працівника як окремої особистості, як важливого члена колективу фрармацевтичної організації, що має спільні цілі та йде до конкретної мети. Встановлено, що постійне розширення низки засобів нематеріальної мотивації праці на підставі врахування методів психологічного стимулювання, в поєднанні з ентузіазмом та оптимістичним поглядом на життя, дозволяє ефективно справлятися 3 найскладнішим завданням для керівника фрармацевтичної організації - мотивацією персоналу.

\section{ИССЛЕДОВАНИЕ РОЛИ ПСИХОЛОГИЧЕСКОГО СТИМУЛИРОВАНИЯ ПЕРСОНАЛА В СОЦИАЛЬНОМ МЕНЕДЖМЕНТЕ ФАРМАЦЕВТИЧЕСКИХ ОРГАНИЗАЦИЙ}

\section{А. А. Котвицкая, О. Н. Воронина, И. В. Кубарева, Н. В.Чмихало}

Национальный фрармацевтический университет, Харьков

socpharm@ukr.net

Цель работы. Проведение исследования роли психологического стимулирования персонала в социальном менеджменте фрармацевтических организаций.

Материалы и методы. Использованы методы научного анализа, в частности его приемы обобщения и группировки, а также социологические методы исследования.

Результаты и обсуждение. В ходе проведения исследования отмечено психологические методы социального менеджмента, фракторы психологического стимулирования персонала и определено следующее: 68,9 \% опрошенного персонала фрармацевтических организаций указали на то, что в их практической деятельности не в полной мере используются психологические прийомы стимулирования персонала, недостаточно используется метод формирования рабочих групп по критерию психологической совместимости персонала (72,8 \%) и почти не используется психологически-организационный метод стимулирования персонала (86,6 \%), то есть при организационном нормировании и регламентировании труда почти не учитывается индивидуальная психология сотрудника фрармацевтической организации.

Выводы. Результаты исследования свидетельствуют о повышении роли именно психологического стимулирования персонала в социальном менеджменте фрармацевтических организаций, что объясняется изменениями в структуре современного общественного труда, его интеллектуализации и ростом социально-культурного и профеессионального уровня персонала. Отмечено, что обязательной необходимостью является оценка каждого сотрудника как отдельной личности, как важного члена коллектива фрармацевтической организации, который имеет совместные цели с организацией и стремиться к достижению конкретной поставленной цели. Психологическое стимулирования персонала должно быть в полной мере применено в социальном менеджменте фрармацевтической организации с целью повышения социальной активности сотрудников.

Ключевые слова: психологическое стимулирование; персонал; социальный менеджмент; фрармацевтические организации.

ISSN 2312-0967. Pharmaceutical review. 2017. № 2 
Фармацевтичний менеджмент, маркетинг та логістика

Pharmaceutical management, marketing and logistics

\title{
RESEARCH OF THE ROLE OF PSYCHOLOGICAL STYMING OF PERSONNEL IN THE SOCIAL MANAGEMENT OF PHARMACEUTICAL ORGANIZATIONS
}

\author{
A. A. Kotvitskaya, O. N. Voronina, I. V. Kubareva, N. V. Chmihalo \\ National University of Pharmacy, Kharkiv \\ socpharm@ukr.net
}

The aim of the work. Conducting research on the role of psychological stimulation of personnel in the social management of pharmaceutical organizations.

Materials and Methods. The methods of scientific analysis, in particular, its methods of generalization and grouping, as well as sociological methods of research, are used.

Results and Discussion. In the course of the study we noted the psychological methods of social management, psychological factors motivating staff and determined as follows: $68.9 \%$ of those surveyed pharmaceutical companies staff indicated that their practice is not fully used psychological - technology stimulation of the personnel, under-utilized method of formation working groups on the criteria of psychological compatibility of staff $(72.8 \%)$ and almost never uses psychological - organizational method staff stimulating (86.6 \%), ie at the institutional normalization and the regulation of labor is almost not taken into account the psychology of the individual employee of a pharmaceutical company.

Conclusions. The results of the research testify to the increased role of psychological stimulation of personnel in the social management of pharmaceutical organizations, which is explained by changes in the structure of modern social labor, its intellectualization and the growth of the socio-cultural and professional level of the staff. It is noted that it is mandatory to assess each employee as an individual person as an important member of the collective of a pharmaceutical organization that has joint goals with the organization and strive to achieve a specific goal. Psychological incentives for staff should be fully applied in the social management of the pharmaceutical organization in order to increase the social activity of employees.

Key words: psychological stimulation; personnel; social management; pharmaceutical organizations.

\section{Список літератури}

1. Балабанова Л. В. Управління персоналом : підручник / Л. В. Балабанова, О. В. Сардак. - К. : Центр учбової літератури, 2011. - 468 с.

2. Друкер П. Классические работы по менеджменту / П. Друкер - М. : Альпина Бизнес Букс, 2008. - 220 с.

3. Кубарєва І. В. Формування сучасної кадрової стратегії у системі менеджменту фрармацевтичних організацій / І. В. Кубарєва, Н. В. Чмихало, О. М. Вороніна // «Професійний менеджмент в сучасних умовах розвитку ринку» : матер. допов. $\vee$ наук.-практ. конф. з міжнар. уч. (1 листоп. 2016 р.): збірн. - X. : Монографр. 2016. - C. 221-223.

\section{References}

1. Balabanova LV, Sardak OV. Management of personnel. [Управління персоналом] Kiev: Center of educational literature; 2011. Ukrainian.

2. Druker P. Classical works on management. [Классические работы по менеджменту] Moscow: Alpina Business Books; 2008. Russian.

3. Kubareva IV, Chmihalo NV, Voronina OM. Formulation of the human resources strategy in the management of pharmaceutical organizations. In: I. V. Kubarev NV Chmihalo OM, Voronina OM. Professional management in everyday life in the development of the market: The materials of the $\mathrm{V}$ scientific-practical conference for the international participants (1 November, 2016): Kharkiv: Monograph; 2016.Ukrainian
4. Толочко В. М. Кадрове забезпечення діяльності 3 соціального захисту в аптечних закладах / В. М. Толочко, М. В. Зарічкова : метод. рек. - Х. : НФаУ, 2015. - 20 с. 5. Хандій О. О. Управління персоналом підприємства: концептуальне визначення та механізми розвитку : монограсрія / О. О. Хандій. - Луганськ : Вид-во СНУ ім. В. Даля, 2010. - 240 с.

6. Щербак В. Г. Інноваційні аспекти управління трудового потенціалу : монографія / В. Г. щербак. - Х. : XHEY, 2009. - 332 c.

4. Tolochko VM. Staffing of activities of social protection activities in pharmacies. [Кадрове забезпечення діяльності з соціального захисту в аптечних закладах] Kharkiv: National University of Pharmacy; 2015. Ukrainian. 5. Handiy OO. Personnel management: conceptual definition and development mechanisms. [Управління персоналом підприємства: концептуальне визначення та механізми розвитку] Lugansk: East-Ukrainian University named after V. Dal; 2010. Ukrainian.

6. Scherbak VG. Innovative aspects of managing labor potential [Інноваційні аспекти управління трудового потенціалу] Kharkiv: Kharkiv National University of Economics; 2009. Ukrainian.

Отримано 12.05.2017

ISSN 2312-0967. Фармацевтичний часопис. 2017. № 2 